\title{
The Investigation of the Relationship between Accruals Quality and Corporate Cash Holdings in Firms Listed in Tehran Stock Exchange (TSE)
}

\author{
Bager Mokhtari \\ M. A. Student in Accounting, Islamic Azad University, Hamedan Branch, Iran \\ E-mail: b_mokhtari27@yahoo.com \\ Saeid Jabbarzadeh Kangarlouei \\ Department of Accounting, Islamic AzadUniversity, Orumieh Branch,OrumiehIran \\ E-mail: jabbarzadeh.s@gmail.com
}

Telephone: 98-914-348 -0277

\section{Morteza Motavassel}

M.A. student in Accounting, Islamic Azad University, West Azarbyjan Science and Research Branch, Iran

E-mail: mortymot@yahoo.com

Received: January 26, 2012

Accepted: May 17, 2012 Published: July 1, 2012

doi:10.5296/jmr.v4i3.1790

URL: http://dx.doi.org/10.5296/jmr.v4i3.1790

\begin{abstract}
Given the increasing importance of liquidity, factors affecting cash holdings have attracted many researchers. In this study, using data from the financial statements of companies listed in Tehran Stock Exchange (TSE), 76 companies are selected as samples. The impact of accruals quality on cash holdings are evaluated using 11 control variables for the period between the years 2003 to 2009 through multivariate linear regression. The results show that the effect of discretionary accrual quality, leverage, capacity to generate cash flows, dividend, debt maturity structure, growth options and financial distress on cash holdings is not statistically significant. On the other hand, non-discretionary accruals quality, size, bank debt,
\end{abstract}




\section{Macrothink}

Journal of Management Research ISSN 1941-899X 2012, Vol. 4, No. 3

opportunity cost of keeping cash, cash flows from previous year operation, respectively, are the most significant factors affecting cash holdings.

Keywords: Accruals Quality, Corporate Cash Holdings, Trade of Theory, Pecking Order Theory, Tehran Stock Exchange 


\section{Introduction}

Cash holdings is one of the most important figures of every firm's balance sheet. There are three theoretical models to explain firm characteristics influence cash holdings decisions. First, the Trade-off Theory (TOT) postulates that firms identify their optimal level of cash holdings by weighting the marginal costs and marginal benefits of holding cash. The benefits related to cash holdings are the following: reduces the likelihood of financial distress, allows the pursuance of investment policy when financial constraints are met, and minimizes the costs of raising external funds or liquidating existing assets. The main cost of holding cash is the opportunity cost of the capital invested in liquid assets. Second, the pecking order theory (POT) of Myers (1984), states that to minimize asymmetric information costs and other financing costs, firms should finance investments first with retained earnings, then with safe debt and risky debt, and finally with equity. This theory suggests that firms do not have target cash levels, but cash is used as a buffer between retained earnings and investment needs. Finally, the free cash flow (FCF) theory of Jensen (1986) suggests that managers have an incentive to build up cash to increase the amount of assets under their control and to gain discretionary power over the firm investment decision. Cash reduces the pressure to perform well and allows managers to invest in projects that best suit their own interests, but may not be in the shareholders best interest (Ferreira and Vilela, 2004).

Dechow and Dichev (2002) define accrual quality as the extent to which accruals map into cash flows realization where a poor match signifies poor accruals quality. poor earnings quality generates internal and external uncertainties that make it necessary for a firm to hold cash at a level higher than the norm. The financial statements of a firm provide important information for computing the firm's current and future cash flows. The accruals reported on the balance sheet are an important component in the computation of cash flow. When the quality of reported accruals is poor, the computed cash flow fluctuates for reasons unrelated to the business risk of a firm. Link between poor earnings quality and the devaluation of cash holdings runs through balance sheet accruals. Accruals figure prominently in computing cash flow from accounting earnings (Sun et al., 2011). García-Teruel and Martínez-Solano (2009) assert that firms with poor accruals quality hold higher cash levels than firms with good accruals quality. Consequently, reporting high-quality information in terms of accruals allows firms to hold lower levels of cash, reducing unproductive liquid resources on their balance sheets. Therefore, accounting quality reduces information asymmetries that impede efficient corporate investment policies, and provide valuable insights for managers, investors, creditors and researchers. They also demonstrate that enhancing accounting quality firms might improve the management of cash holdings, reducing their cash levels in balance sheet and, consequently, improving investment efficiency.

\section{Literature Review}

Bigelli and Sánchez-Vidal (2011) found that cash holdings are significantly related with smaller size, higher risk and lower effective tax rates, supporting predictions TOT. More cash is also held by firms with longer cash conversion cycles and lower financing deficits, as predicted by the financing POT. They also show that dividend payments are associated with 
more cash holdings, and both bank debt and net working capital represent good cash-substitutes and cash-rich companies are more profitable, pay more dividends and invest more in a medium-term future horizon.

In addition, there are other factors influencing the level of cash holdings. Liu and Maue (2011) studied the relationship between corporate cash holdings and CEO compensation incentives and found a positive relation between CEO risk-taking incentives and cash holdings, and a negative relation between risk-taking and the value of cash to shareholders. They report that negative effect of risk-taking on the value of cash is robust after controlling for corporate governance, is stronger in firms with high leverage, is reversed for unlevered firms, and is not present in financially constrained firms. They also find that the likelihood of liquidity covenants in new bank loans is increasing in CEO risk-taking incentives. Tong (2010) investigated the relationship between CEO risk incentives and corporate cash holdings with higher CEO risk incentives have less cash holdings. The results show that the value of cash holdings is higher in firms with higher CEO risk incentives, which are consistent with risk-related agency theory. Kuan et al. (2010) investigated the relationship between cash holdings and corporate governance in family-controlled firms. Their results show that the impact of corporate governance, with its separation of control rights and cash flow rights, director-ownership-in-pledge ratio and proportion of independent directors on cash policy, differs between family-controlled and nonfamily-controlled firms. Subramaniam et al. (2011) find that diversified firms hold significantly less cash than their focused counterparts do. They find that the theories that rely on the potentially effective use of asset sales of non-core segments of diversified firms to generate cash, and the increased agency/influence costs in diversified firms do not offer an economically significant explanation for the lower cash holdings among diversified firms.

Exploring the relationship between accruals quality and corporate cash holdings in the Spanish stock exchange over the period from 1995 to 2001, García-Teruel and Martínez-Solano (2009) show that firms with good accruals quality hold lower cash levels than firms with poor accruals quality. Their finding suggests that the quality of accounting information may reduce the negative effects of information asymmetries and adverse selection costs, allowing firms to reduce their level of corporate cash holdings. Their results also show that cash holdings decrease when firms increase their use of bank debt and in the presence of cash substitutes. In contrast with this, firms with higher cash flow hold higher levels of cash (García-Teruel and Martínez-Solano, 2009). More recently, García-Teruel et al. (2010) studied the relationship between accruals quality and debt maturity structure. Their results suggest that firms with higher accruals quality can obtain a longer maturity of their debt than those firms with lower accruals quality. Moreover, Sun et al. (2011) show that poor earnings quality has a negative impact on the value of corporate cash holdings and a positive impact on the level of cash reserves. They find that the negative effect of poor earnings quality either neutralizes or more than offsets the positive effect of excess cash on firm value. Mclnnis and Collins (2011) argue that accruals quality improves after analysts begin issuing cash flow forecasts 


\section{Methodology and Data Collection}

The present study is applied research using descriptive-correlation method. F and T-statistic are used to test significance of estimated model. The statistical method used in this study is regression using panel data and documental method to develop research literature. In addition, TSE database, Tadbirpardaz software and companies` annual reports are used to collect data for hypotheses test. To do so, 76 firms` financial statements selected from TSE are studied during the period of 2003-2009 after considering following conditions:

1. Firms 'fiscal year end must be at the end of year and they have not changed their fiscal year.

2. Sample firms must have listed from 2001.

3. Transaction intervals must not be more than 1 month.

4. Data must be available for testing hypotheses.

5. Sample firms must not be investment or brokerage.

Since each firm has 7 financial statements issued during 2003 to 2009, total observation is 532 year-firm. However, it is necessary for some variables to calculate their changes in one year before and one year forward and as a result of this condition, total year observations are reduced by 5 firms decreasing total observation by 380 year-firm. Finally, after collecting data in Excel software, SPSS software is used to analyze the data.

\section{Research Hypotheses}

$\mathrm{H}_{1}$ : accruals quality has a significant impact on corporate cash holdings.

$\mathrm{H}_{2}$ : non-discretionary accruals quality has more impact on corporate cash holdings than discretionary accruals quality.

\section{Research Variables}

According to Dechow and Dichev (2002), variables that may affect accruals persistency are controlled including growth opportunities, size, debt maturity structure, bank debt, leverage, opportunity cost of the capital invested in liquid assets, capacity to generate cash flows, dividend and cash holdings. However, in this research cash holdings variable is measured by García-Teruel et al. (2009) model as following:

CASHit $=\beta_{0}$ CASHit $-1+\beta_{1}$ AQ_DDit $+\beta_{2}$ GROWPit $+\beta_{3}$ SIZEit $+\beta_{4}$ LTDEBTit $+\beta_{5}$ BANKDit $+\beta_{6}$ RSPREADit $+\beta_{7}$ LEVit $+\beta_{8}$ LIQit $+\beta_{9}$ CFLOW $+\beta_{10}$ ZSCOREit $+\beta_{11}$ DIVit $+\eta i+\lambda t+\mathrm{vi}$

CASHit measures cash holdings; AQ_DDit is an inverse proxy of accruals quality; GROWPit measures growth options; SIZEit is firm size; LTDEBTit is long-term leverage; BANKDit is bank debt; RSPREADit is opportunity cost of keepingcash; LEVit is leverage; LIQitis investment in other liquid assets; CFLOWit is cash flow; ZSCOREit is the probability of financial distress; DIV is a dummy variable that takes the value 1 if the firm has paid dividends; $\eta i$ represents firms specific effects (unobservable heterogeneity); $\lambda t$ is temporary effects; and vit is random disturbances. 


\section{Macrothink}

Journal of Management Research

ISSN 1941-899X

2012, Vol. 4, No. 3

Following the previous empirical studies, accruals quality is used as a proxy for financial reporting quality as presented by Dechow and Dichev (2002). Dechow and Dichev`s measure of accruals is changes in working capital and also their proxy for cash flows related to accruals are realized cash flows from operations. The residuals from the regression reflect the magnitude of accruals unrelated to cash flow realizations and the standard deviation of these residual is a measure of accruals quality where higher standard deviation denotes lower quality (Dechow and Dichev, 2002).

$$
\text { WCAit }=c+\lambda 1 \text { CFOit }-1+\lambda 2 \text { CFOit }+\lambda 3 \text { CFOit }+1+\varepsilon i t
$$

Where:

WCAit: working capital accruals

CFOit-1: cash flow from previous year operation

CFOit: cash flow from present year operation

CFOit+1: cash flow from next year operation

Eit: residual indicating accrual error term

All the variables are deflated by average total assets.

In this model, working capital accruals is calculated as following:

$$
\text { WCAit }=\Delta \text { CAit }-\Delta \text { CLit }-\Delta \text { Cashit }+\Delta \text { STDEBTit }
$$

$\Delta \mathrm{CA}$ : changes in current assets

$\Delta$ Cash: changes in cash and cash equivalent

$\triangle$ STDEBT: changes in short-term bank debt

Residuals for each year-firm observation is inverse proxy of working capital accruals that is AQit= $=$ git $\mid$

Dechow and Dichev (2002) model emphasizes on four innate or non-discretionary components of accruals quality including operating cycle, firm size, volatility of sales and cash flow, and proportion of losses. Many researchers have used this model to investigate the degree of non-discretionary accruals on accruals quality, which is shown as following:

$$
A Q=\beta_{0}+\beta_{1} \text { Size }+\beta_{2} \sigma(C f o)+\beta_{3} \sigma(\text { Sales })+\beta_{4} \text { Opercycle }+\beta_{5} N e g E a r n+\text { cit }
$$

Where:

Size: firm size

Cfo: cash flow

Opercycle: operating cycle

NegEarn: Negative earnings 


\section{Empirical Results}

Table 1. Descriptive statistic

\begin{tabular}{|c|c|c|c|c|c|c|c|c|}
\hline variable & mean & median & $\min$ & $\max$ & $\begin{array}{l}\text { Standard } \\
\text { deviation }\end{array}$ & skewness & kurtosis & variation \\
\hline CASHt & 0.044 & 0.046 & 0.000044 & 0.998 & 0.144 & 5.127 & 27.157 & 0.021 \\
\hline CASHt-1 & 0.040 & 0.006 & 0.000044 & 0.992 & 0.133 & 5.498 & 32.562 & 0.018 \\
\hline AQ-DD & 0.112 & 0.110 & 0.998 & 0.138 & 0.014 & 0.881 & -0.562 & 0.000 \\
\hline GROWP & 3.472 & 2.665 & -0.334 & 9.878 & 2.693 & 0.924 & -0.265 & 7.254 \\
\hline SIZE & 5.525 & 5.396 & 3.976 & 7.922 & 0.718 & 0.901 & 0.991 & 0.516 \\
\hline LTDEBT & 0.166 & 0890 & 0.001 & 0.999 & 0.188 & 2.045 & 4.268 & 0.035 \\
\hline BANKD & 0.408 & 0.392 & 0.000 & 0.999 & 0.259 & 0.344 & -0.568 & 0.068 \\
\hline RSPREAD & 0.221 & 0.197 & -0.499 & 0.951 & 0.150 & 0.987 & 3.287 & 0.023 \\
\hline LEV & 0.624 & 0.650 & 0.008 & 0.992 & 0.198 & -0.858 & 0.665 & 0.039 \\
\hline LIQ & 0.232 & 0.023 & -0.991 & 0.952 & 0.245 & -0.376 & 2.272 & 0.060 \\
\hline CFLOW & 0.227 & 0.195 & -0.873 & 0.844 & 0.206 & -0.298 & 3.576 & 0.043 \\
\hline Zscore & 0.069 & 0.104 & -0.257 & 2.924 & 1.681 & -22.383 & 511.396 & 2.827 \\
\hline DIV & 0.780 & 1.000 & 0.000 & 1.000 & 0.416 & -1.343 & -0.173 & 0.173 \\
\hline
\end{tabular}

According to Table 1, mean cash holdings at the beginning of year is 0.044 which means that firms of TSE hold 0.044 of their assets on cash on average, less than the US and UK firms according to the research of Ozkan and Ozkan (2004) and Kim et al. (1997). Firm's size variable spreads from 3.9 to 7.9 showing that sample firms are in the vast range of small and large firms. The normality test of sample shows that the sample has normal distribution. In addition, because the cross-sectional and time series methods are used to test research hypotheses, the combined data includes 1120 observation. 


\section{Macrothink}

6.1 Hypotheses Test

Table 2. Pierson`s correlation matrix

\begin{tabular}{ccc}
\hline Variable & CASH & AQ-DD \\
\hline CASH & 1 & 0.121 \\
sig & 0.018 & 0.018 \\
AQ-DD & 0.121 & 1 \\
sig & 0.018 & 0.018 \\
\hline
\end{tabular}

According to Table 2, there is a significant and negative (since accrual quality variable is inverse proxy of accruals quality) relationship between cash holdings and accruals quality, proving García-Teruel and Martínez-Solano (2009) model. However, considering the significant relationship between cash holdings and accruals quality, the hypotheses are tested.

6.1.1 First Hypothesis Test 
Table 3. Results of the first hypothesis test

\begin{tabular}{|c|c|c|c|c|}
\hline $\begin{array}{l}\text { CASHit }= \\
+\beta_{6} R S P 1\end{array}$ & $\begin{array}{l}\text { Hit-1 }+\beta_{1} A \\
+\beta_{7} L E V i t+\end{array}$ & $\begin{array}{l}D i t+\beta_{2} \text { GROWPit }+\beta_{3} S \\
\text { LIQit }+\beta_{9} C F L O W+\beta_{10}\end{array}$ & $\begin{array}{l}3_{4} L T D E B T i t \\
\text { Eit }+\beta_{11} D I\end{array}$ & $\begin{array}{l}\text { NKDit } \\
t+\mathrm{vi}\end{array}$ \\
\hline variable & coefficient & Standard deviation & T- statistic & sig \\
\hline CASHit-1 & 0662 & 0.133 & 22.093 & 0.000 \\
\hline AQ_DDit & 0.081 & 0.014 & 4.302 & 0.000 \\
\hline GROWPit & 0.002 & 3.724 & 0.122 & 0.903 \\
\hline SIZEit & 0.117 & 0.717 & 4.830 & 0.000 \\
\hline LTDEBTit & -0.034 & 0.534 & -1.624 & 0.105 \\
\hline BANKDit & 0.182 & 0.922 & 7.296 & 0.000 \\
\hline RSPREADit & 0.073 & 1.790 & 2.290 & 0.023 \\
\hline LEVit & 0.024 & 1.213 & 1.038 & 0.300 \\
\hline LIQit & -0.239 & 19.286 & -1.324 & 0.186 \\
\hline CFLOW & 0.012 & 1.752 & 0.619 & 0.536 \\
\hline DIVit & 0.008 & 0.438 & 0.401 & 0.689 \\
\hline ZSCOREit & 0.176 & 1.985 & 0.994 & 0.321 \\
\hline constant & ---- & --- & -6.878 & 0.000 \\
\hline \multirow{4}{*}{$\begin{array}{c}\text { Durbin-Watson } \\
\text { statistic }\end{array}$} & \multirow{4}{*}{\multicolumn{2}{|c|}{1.935}} & $K^{L}$ & 0.871 \\
\hline & & & & 0.867 \\
\hline & & & $\mathrm{F}$ & 206.909 \\
\hline & & & $\mathrm{F}$ & 0.000 \\
\hline
\end{tabular}

As a result, estimated model is obtained as following:

CASHit $=0 / 668($ CASHit -1$)+0 / 028\left(A Q \_\right.$Innatet $)-0 / 004(A Q$ freet $)+0 / 0029($ GROWPit $)$ +0/114SIZEit-0/049(LTDEBTit)+0/182(BANKDit)+0/057(RSPREADit)+0/26(LEVit)-0/342( LIQit $)+0 / 010($ CFLOW $)+0 / 279($ ZSCOREit $)+0 / 010($ DIVit $)-0 / 147$

Since coefficient of AQ_DDit as an inverse proxy of accruals quality is 0.081 , there is a significant and negative (since accrual quality variable is inverse proxy of accruals quality) relationship between cash holdings and accruals quality, that is, firms with higher accrual 
quality hold less cash. Coefficient of CASHit-1is 0.662 showing that there is a lag in current cash holdings adjustment to optimal level of cash holdings. Coefficient of SIZEit is 0.117 indicating that contrast to TOT, the relationship between cash holdings and firm's size is positive, that is, increasing firm's size leads to increase in cash holdings, which is according to FCF hypothesis. Coefficient of LTDEBTit is -0.034 , which is not significant in consistency with TOT. Coefficient of LEVit is 0.3 which is not significant showing that there is a not a relationship between cash holdings and leverage.

Therefore, considering the F-statistic (0.000), the first hypothesis is accepted, that is, accruals quality because of less information asymmetry, results in decreasing the level of cash holdings.

6.1.2 Second Hypothesis Test 


\section{Macrothink}

Table 3. Results of the second hypothesis test

\begin{tabular}{|c|c|c|c|c|}
\hline \multicolumn{5}{|c|}{$\begin{array}{l}\text { CASHit }=\beta_{0} \text { CASHit }-1+\beta_{1} \text { AQ_DDit }+\beta_{2} \text { GROWPit }+\beta_{5} \text { SIZEit }+\beta_{4} L T D E B T i t+\beta_{8} \text { BANKDit } \\
+\beta_{6} \text { RSPREADit }+\beta_{7} L E V i t+\beta_{8} \text { LIQit }+\beta_{9} \text { CFLOW }+\beta_{10} \text { ZSCOREit }+\beta_{11} D I V i t+\eta i+\lambda t+v i\end{array}$} \\
\hline Variable & coefficient & Standard deviation & T- statistic & sig \\
\hline CASHit-1 & 0.668 & 0.139 & 21.558 & 0.000 \\
\hline$A Q \_$Innate $t$ & 0.028 & 0.038 & 0.655 & 0.013 \\
\hline$A Q_{-}$free $t$ & -0.004 & 0.223 & -0.191 & 0.848 \\
\hline GROWPit & 0.002 & 3.724 & 0.125 & 0.901 \\
\hline SIZEit & 0.114 & 0.717 & 4.519 & 0.000 \\
\hline LTDEBTit & -0.049 & 0.534 & -1.260 & 0.049 \\
\hline BANKDit & 0.182 & 0.922 & 7.069 & 0.000 \\
\hline RSPREADit & 0.057 & 1.790 & 1.617 & 0.007 \\
\hline LEVit & 0.026 & 1.213 & 0.099 & 0.272 \\
\hline LIQit & -0.347 & 19.286 & -1.877 & 0.041 \\
\hline CFLOW & 0.010 & 1.752 & 0.525 & 0.600 \\
\hline DIVit & 0.010 & 0.438 & 0536 & 0.596 \\
\hline ZSCOREit & 0.279 & 1.985 & 1.545 & 0.023 \\
\hline \multirow[t]{2}{*}{ constant } & \multirow[t]{2}{*}{----} & \multirow[t]{2}{*}{---} & -4.901 & 0.000 \\
\hline & & & $R^{2}$ & 0.865 \\
\hline \multirow[t]{3}{*}{$\begin{array}{l}\text { Durbin-Watson } \\
\text { statistic }\end{array}$} & & \multirow[t]{3}{*}{1.838} & $R^{2}$ & 0.860 \\
\hline & & & $\mathrm{F}$ & 180.240 \\
\hline & & & $\mathrm{F}$ & 0.000 \\
\hline
\end{tabular}

As a result, estimated model is obtained as following:

CASHit $=0 / 662($ CASHit1) $+0 / 081($ AQ_DDit $)+0 / 002($ GROWPit $)+0 / 117$ (SIZEit) $0 / 034($ LTDEB Tit $)+0 / 182(B A N K D i t)+0 / 073(R S P R E A D i t)+0 / 024($ LEVit $)-0 / 239$ (LIQit) $+0 / 012(\quad$ CFLOW $)$ +0/008(ZSCOREit) $+0 / 176($ DIVit $)-0 / 248$

Since coefficient of $A Q_{-}$Innatet as an inverse proxy of accruals quality is 0.208 , there is a significant and negative relationship between cash holdings and accruals quality, in other words, firms with higher accrual quality hold less cash. Coefficient of $A Q_{-}$free $t$ as an 
inverse proxy of accruals quality is -0.004 showing that there is not a significant relationship between cash holdings and accruals quality, so managers may not affect cash holdings level by accounting choices and opportunistic behavior. Coefficient of CASHit-1 is 0.668 showing that there is a lag in current cash holdings adjustment to optimal level of cash holdings. Coefficient of GROWPit is 0.002 , which is not significant, contrast to TOT predicting a positive relationship between investment opportunity and cash holdings, and FCF anticipating a negative relationship between them. Coefficient of LEVit is 0.026 which is not significant indicating that there is a not a relationship between cash holdings and leverage.

Therefore, there is no relationship between discretionary accruals quality and corporate cash holdings. So the second hypothesis is accepted.

\section{Results and Discussion}

In this study using 76 firm's data listed in Tehran Stock Exchange (TSE), the relationship between accruals quality and corporate cash holdings during the period of 2003 to 2009 is investigated. To do so, two hypotheses are developed: The first hypothesis postulates that accruals quality has a significant impact on corporate cash holdings, which is accepted. In addition, the second hypothesis predicting that non-discretionary accruals quality has more impact on corporate cash holdings than discretionary accruals quality is also accepted. These results are obtained using García-Teruel and Martínez-Solano (2009) model through controlling for 11 variables. The results show that the effect of discretionary accrual quality, leverage, capacity to generate cash flows, dividend, debt maturity structure, growth options and financial distress on cash holdings is not statistically significant. On the other hand, non-discretionary accruals quality, size, bank debt, opportunity cost of keeping cash, cash flow from previous year operation, respectively, are the most significant factors affecting cash holdings. These findings are consistent with the results of García-Teruel and Martínez-Solano (2009). These findings show that managers should consider earnings quality in cash holdings management to enable them reduce freeze cash in firm. Our results also suggest that because firms with good accruals quality might improve the management of their investments, therefore, investors and creditors may apply the quality of accounting information as a valuable factor into their discount rates and debt contract terms.

\section{References}

Dechow, P., Dichev, I. (2002). The quality of accruals and earnings: the role of accrual estimation errors. Accounting Review, 35-59. http://dx.doi.org/10.2308/accr.2002.77.s-1.35

Ferreira, M.A., Vilela, A.S. (2004). Why do firms hold cash? Evidence from EMU countries. European Financial Management, $\quad$ 10(2), 295-319. http://dx.doi.org/10.1111/j.1354-7798.2004.00251.x

Garcia-Teruel, P. J., Martinez-Solano, P., \& Sánchez-Ballesta. J. P. (2010). Accruals Quality and Debt Maturity Structure, ABACUS, 46(2), 188-210. http://dx.doi.org/10.1111/j.1467-6281.2010.00312.x 


\section{Macrothink}

Journal of Management Research

ISSN 1941-899X 2012, Vol. 4, No. 3

Garcia-Teruel, P. J., Martinez-Solano, P., \& Sánchez-Ballesta. J. P. (2009). Accruals quality and corporate cash holdings. Journal of Accounting and Finance.

Kim, C.S., Mauer, D. C., \& Sherman, A. E. (1998). The determinants of corporate liquidity: Theoryand evidence. Journal of Financial and Quantitative Analysis, 33(3), 335-359. http://dx.doi.org/10.2307/2331099

Kuan, T.H., Li, C. SH., \& Chu, SH. H. (2010). Cash holdings and corporate governance in family-controlled firms. Journal of Business Research, 757-764.

Liu, Y., \& Maue, D.C. (2011). Corporate cash holdings and CEO compensation incentives. Journal of Financial Economics, 183-198. http://dx.doi.org/10.1016/j.jfineco.2011.05.008

Mclnnis, J., \& Collins, D, W. (2011). The effect of cash flow forecasts on accruals quality and benchmark beating. Journal of accounting and economics, 211-239.

Ozkan, A., \& Ozkan, N. (2004). Corporate Cash Holdings: An Empirical Investigation of UK Companies. Journal of Banking \& Finance, 28, 2103-2134. http://dx.doi.org/10.1016/j.jbankfin.2003.08.003

Subramaniam, V., Tang, T. T., Yue, H., \& Zhou., X. (2011). Firm structure and corporate cash holdings. Journal of Corporate Finance, 759-773. http://dx.doi.org/10.1016/j.jcorpfin.2010.06.002

Sun, Q., Yung, K., \& Rahman, H. (2011). Earnings quality and corporate cash holdings, Accounting and Finance.

Tong, Z. (2010). CEO Risk Incentives and Corporate Cash Holdings. Journal of Business Finance \& Accounting, 1248-1280. http://dx.doi.org/10.1111/j.1468-5957.2010.02208.x 